\section{Predictors of long-term neurological outcomes in non-accidental head injury}

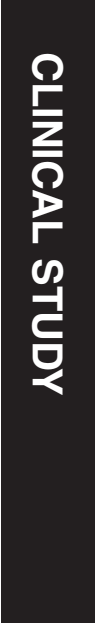

${ }^{1}$ Department of Ophthalmology, Greenlane Clinical Centre, Auckland, New Zealand

${ }^{2}$ Department of Ophthalmology, New Zealand National Eye Centre, Faculty of Medical and Health Sciences, University of Auckland, Auckland, New Zealand

${ }^{3}$ Royal Gwent Hospital, Newport, UK

Correspondence:

S Dai, Department of Ophthalmology, Greenlane Clinical Centre, Private Bag 92189, Auckland 1024, New Zealand

E-mail: shuandai@me.com

Received: 3 October 2016 Accepted in revised form: 25 October 2017

Published online:

8 December 2017 neurological outcome and eventual death.
CF Chong ${ }^{1,2}$, SL Misra², JA Escardo-Paton ${ }^{3}$ and $S$ Dai $^{1,2}$

Conflicting to other studies, younger children presented better neurological outcomes.

Eye (2018) 32, 608-614; doi:10.1038/eye.2017.266; published online 8 December 2017

\section{Introduction}

Non-accidental head injury (NAI) is an inflicted traumatic brain injury upon a child, often resulting in debilitating long-term neurological deficits and at times death. ${ }^{1} \mathrm{NAI}$ is otherwise also referred as shaken baby syndrome, whiplash-shaking injury, inflicted head trauma, and abusive head trauma. ${ }^{2}$ The neurological deficits, including learning disabilities, motor disabilities, cortical blindness, and epilepsy, occur in almost $60 \%$ of surviving children. ${ }^{1}$ The majority of these injuries are inflicted in the form of physical abuse on young defenseless children under the age of 2 years. ${ }^{3}$ Not surprisingly, these injuries are fatal in about $20 \%$ of these children. ${ }^{4}$

The incidence of NAI in the United Kingdom was 14.2/100 000 in the year 1998-1999, whereas a retrospective study published in 2005 reported an increased figure of 24.6/100 000., ${ }^{5,6}$ In New Zealand, the incidence of NAI in children under the age of 2 years is estimated between 14.7 and $19.6 / 100000$ population. ${ }^{7}$ However, this incidence is 32.5-38.5/100 000 among the indigenous New Zealand Māori population. ${ }^{7}$ Interestingly, the incidence of mild cases of NAI is as high as 750 cases per 100000 people per year in New Zealand. ${ }^{8}$

Ophthalmologists are often consulted in an acute setting of every case of suspected NAI in order to ascertain the presence of retinal haemorrhages. Retinal haemorrhages have a strong predictive value of NAI with odd ratios of 14.7 , as computed by multilevel logistic regression analysis in a systematic review of six relevant studies. ${ }^{9}$ The characteristic findings are that retinal haemorrhages occur simultaneously in different layers of the retina and extend to the 
far peripheral retina. These retinal haemorrhages are often extensive and too numerous to count. ${ }^{10,11}$ Reportedly, the presence of a macular retinoschisis (a dome-shaped haemorrhage within the retina at the macula) is highly indicative of NAI. ${ }^{12-14}$

Although the severity of retinal haemorrhages and the presence of retinoschisis is associated with the severity of acute neurological injury and death following NAI, 15,16 these studies have not yet examined the long-term prognostic value in survivors.

The current retrospective study aimed to investigate the correlation between the acute findings in NAI and longterm neurological outcome. This information might prove beneficial in forecasting victims' prognoses for caregivers, society, and health-care providers.

\section{Materials and methods}

The location of the study was Blind and Low Vision Education Network New Zealand, Homai Campus, Auckland, New Zealand. The study was approved by our hospital Research Ethics Committee and followed the tenets of the Declaration of Helsinki.

The medical records of all patients diagnosed with NAI and retinal haemorrhages over a 5-year period (between May 2005 and May 2010) were retrospectively reviewed. Information collected from each medical record included date of birth, gender, ethnicity, injuries sustained, widefield digital retinal images (RetCam-II; Clarity Medical Systems, Pleasanton, CA, USA), visual sequalae, neurological function, and global function. Visual sequalae included non-standardised data collection, that is, reduced visual fields, cortically blind, normal. Visual acuity data were available for only 18 children. Visual acuity was assessed in a variety of age and intellectual appropriate methods, including forced preferential looking, Lea symbols, and Sheridan-Gardiner and Snellen visual acuity. However, these were converted to Snellen equivalents in their medical notes with notation of the method of visual acuity testing to maintain consistency.

Self-described ethnicity was recorded according to the 2006 New Zealand Census data description with six main categories: European, Māori, Pacific peoples, Asian, Middle Eastern/Latin American/African, and others.

Injuries sustained by patients were compiled from medical records, discharge summaries, computed tomography scans, and radiology reports stored on the local hospital's patient software, Concerto and Web1000 computer network system.

Wide-field digital retinal images of all patients were reviewed by an experienced paediatric ophthalmologist (SD) to determine the presence and extent of retinal hemorrhage and macular retinoschisis. Neurological function was measured with the Glasgow Outcome Scale -Extended Pediatric version (GOS-E Ped) ${ }^{17}$ instead of the gold standard Glasgow Outcome Scale-Extended due to its lack of validation in children. The GOS-E Ped was scored (by CFC) according to eight categories: $1=$ upper good recovery to $8=$ death (Table 1 ).

Furthermore, neurological outcomes were defined as the child's functional neurological status at their last followup appointment with their Paediatrician.

Statistical analysis was performed using the IBM SPSS for Windows (Version 21.0; IBM Corp., Armonk, NY, USA). Ordinal logistic regression was used to investigate correlation between variables and neurological outcomes. The explanatory variables used were age of injury, subdural haemorrhage (SDH) — unilateral or bilateral, retinal haemorrhage involving the fovea-unilateral or bilateral and the presence or absence of retinoschisis, and types of retinal haemorrhages. The ordinal outcome of GOS-E Ped score included reduced to normal (GOS-E

Table 1 Glasgow Outcome Score-Extended Pediatric version category definitions

\begin{tabular}{|c|c|c|}
\hline Score & & Definition \\
\hline 1 & $\begin{array}{l}\text { Upper good } \\
\text { recovery }\end{array}$ & Returned to completely to premorbid condition with no detectable sequelae from the head injury \\
\hline 2 & $\begin{array}{l}\text { Lower good } \\
\text { recovery }\end{array}$ & Returned to premorbid condition with residual problems occasionally (less than weekly) affecting child \\
\hline 3 & $\begin{array}{l}\text { Upper moderate } \\
\text { disability }\end{array}$ & Returned to premorbid condition with frequent non physical problems (more than weekly) affecting child \\
\hline 4 & $\begin{array}{l}\text { Lower moderate } \\
\text { disability }\end{array}$ & $\begin{array}{l}\text { Child is independent or behaves age appropriately outside home but suffers constant problems affecting } \\
\text { individual }\end{array}$ \\
\hline 5 & $\begin{array}{l}\text { Upper severe } \\
\text { disability }\end{array}$ & $\begin{array}{l}\text { Dependent on caretaker more so than expected based on age but does not require caretaker to accomplish } \\
\text { tasks a child of this age should be able to do }\end{array}$ \\
\hline 6 & $\begin{array}{l}\text { Lower severe } \\
\text { disability }\end{array}$ & $\begin{array}{l}\text { Dependent on caretaker more so than expected based on age and requires caretaker to accomplish tasks a } \\
\text { child of this age should be able to do }\end{array}$ \\
\hline 7 & Vegetative state & Inability to obey single commands, verbalise, act, react, or interact beyond reflexes \\
\hline 8 & Death & \\
\hline
\end{tabular}


Ped $=1$ ), some neurological impediment (GOS-E Ped = 2-7), or dead (GOS-E Ped =8).

\section{Results}

Thirty-eight children with a clinical diagnosis of NAI were identified during the study period between May 2005 and May 2010. Twelve children died acutely from the injury (died on admission); the remaining 26 children were included in this cross-sectional study. The average age of injury presentation was 9 months (age range 1-37 months) with 24 male and 14 female children (Table 2) The average duration of follow-up in this group was 26 months (range: 11-62 months).

Children in this study were from five of the six ethnic groups in New Zealand. The highest representation was Māori (69\%) followed by Caucasian (17\%), Tongan (10\%), Indian ( $2 \%$ ), and African (2\%). All 38 children had SDH and retinal hemorrhage at the time of initial assessment. Twenty-two (58\%) children had bilateral SDH while bilateral retinal haemorrhage was noted in 29 (74\%) children. Thirteen children presented with some degree of clinical neurological impediment while retinoschisis was noted in 17 children. Nine (53\%) children with retinoschisis died acutely compared with 3 (14\%) without retinoschisis.

Of the 26 surviving children, visual acuity data were available for 18 children. Eleven children had visual acuity better than Snellen visual acuity 6/12, nine without retinoschisis, and two with retinoschisis. The visual acuities were between Snellen 6/12 and 6/60 in three children, and of these three, two had retinoschisis. Four children had visual acuity worse than Snellen 6/60 in the better eye; however, retinoschisis was noted in three of them. Children with poor visual acuity were noted to have more diffuse retinal haemorrhage, retinal haemorrahge involving the fovea, and the presence of retinoschisis. Retinoschisis was significantly associated with worsened visual outcome at the final visit $(P<0.01$; Table 3).

Using ordinal logistic regression models, there was evidence that age of injury was related to outcome $(P=0.004)$, with older children less likely to have good neurological outcome (Table 4). The estimation for the odds ratio of good neurological outcome was observed three times better in unilateral SDH and unilateral retinal haemorrhage compared with bilateral involvement $(P=0.18$ and $P=0.26$, respectively), though the results were statistically insignificant.

Unilateral retinoschisis was associated with a four-time increased chance of poor neurological outcome (GOS-E Ped $=8$ ) compared with a child without retinoschisis. Bilateral retinoschisis was noted to be a predictor of worse neurological outcome with possibly up to seven times the odds of poor long-term neurological outcome, in comparison with no retinoschisis $(95 \%$ confidene interval 0.02-1.2). Although statistical analysis was inconclusive due to the large confidence interval, the estimated odds of poorer neurological outcome was greater in bilateral compared with unilateral retinoschisis and for bilateral compared with no retinoschisis.

\section{Discussion}

The current study investigated the age of injury, laterality of SDH, laterality of retinal hemorrhage, presence of preretinal haemorhages, and presence of macular retinoschisis for prognostic determinant of long-term neurological outcome and visual outcome. To our knowledge, this is the first study to investigate association between retinal haemorrhages and retinoschisis in NAI to predict 'cause and effect' of these injuries to neurological outcome and visual outcome.

Of the four factors studied in this study, only age of injury at presentation corresponded with positive longterm neurological outcome; that is, younger age at the time of acute admission is expected to achieve better neurological outcome. Several studies have reported contradictory findings with younger age leading to higher rates of mortality, morbidity, or cognitive impairment. ${ }^{18,19}$ Notably, a report from the New Zealand Children's Commissioner stated that injury at a later age corresponds with good neurological outcome or poorer outcome at younger age. ${ }^{20}$ Interestingly, some studies have reported no correlation between age of injury and global outcome. ${ }^{21,22}$ Clearly, there is no consensus among clinicians or clinical researchers with regards to the prediction of global outcomes and NAI presentation age. The studies that report on these types of injuries have an age range of about 1-36 months at presentation similar to the current study with an age range of 3-37 months. ${ }^{21,22}$ Arguably, better repair mechanism and good brain plasticity in younger age group potentially leads to positive neurological outcomes. Furthermore, severity of injury at the age of admission possibly has an important role in determining long-term neurological outcomes. The younger children in the current study potentially suffered less severe injuries. Further research on NAI and its comparative outcomes in infants, older children, and adolescents might help in explaining the importance of age at the time of initial injury presentation. ${ }^{22}$

The current study utilised the GOS-E Ped to assess neurological function. ${ }^{17}$ GOS-E Ped provides sensitive results across the injury spectrum along with its ability to detect subtle changes in functional status as compared with standard GOS that can significantly underestimate the impact of brain injury in young children. ${ }^{17,22}$ According to GOS-E Ped, the presence of macular 
Table 2 Outcome of 38 cases of non-accidental head injury with visual sequalae

\begin{tabular}{|c|c|c|c|c|c|c|c|c|c|c|}
\hline \multirow[t]{2}{*}{ Subject } & \multirow{2}{*}{$\begin{array}{l}A I \\
(m o)\end{array}$} & \multirow[t]{2}{*}{ Gender } & \multirow[t]{2}{*}{ Ethnicity } & \multirow[t]{2}{*}{ Clinical features } & \multicolumn{3}{|c|}{ Clinical features } & \multirow{2}{*}{$\begin{array}{l}A F \\
(m o)\end{array}$} & \multirow[t]{2}{*}{ Neurol sequelae } & \multirow{2}{*}{$\begin{array}{l}\text { GOS } \\
\text { E Ped }\end{array}$} \\
\hline & & & & & $S D H$ & RH & Retinoschisis & & & \\
\hline Case 1 & 3 & $\mathrm{~F}$ & $\begin{array}{l}\text { Pacific } \\
\text { people }\end{array}$ & Bilateral SDH, bilateral $\mathrm{RH}$ & $\mathrm{b}$ & $\mathrm{b}$ & $\mathrm{n}$ & 65 & Mild developmental delay & 4 \\
\hline Case 2 & 8 & M & Maori & Right $\mathrm{SDH}$, right $\mathrm{RH}$ & $\mathrm{r}$ & $\mathrm{r}$ & $\mathrm{n}$ & 37 & Normal & 1 \\
\hline Case 3 & 14 & M & Asian & $\begin{array}{l}\text { Left } \mathrm{SDH} \text {, bilateral } \mathrm{RH} \text {, } \\
\text { bilateral retinoschisis }\end{array}$ & 1 & $\mathrm{~b}$ & $\mathrm{~b}$ & & Died & 8 \\
\hline Case 4 & 3 & M & Maori & $\begin{array}{l}\text { Bilateral SDH, bilateral } \mathrm{RH}, \\
\text { right retinoschisis }\end{array}$ & $\mathrm{b}$ & $\mathrm{b}$ & $\mathrm{r}$ & & Died & 8 \\
\hline Case 5 & 3 & M & Maori & $\begin{array}{l}\text { Bilateral } \mathrm{SDH} \text {, bilateral } \mathrm{RH}, \\
\text { right retinoschisis }\end{array}$ & $\mathrm{b}$ & $\mathrm{b}$ & $\mathrm{r}$ & & Died & 8 \\
\hline Case 6 & 7 & $\mathrm{~F}$ & $\begin{array}{l}\text { Pacific } \\
\text { people }\end{array}$ & $\begin{array}{l}\text { Bilateral SDH, bilateral } \mathrm{RH}, \\
\text { right retinoschisis }\end{array}$ & $\mathrm{b}$ & $\mathrm{b}$ & $\mathrm{r}$ & 26 & $\begin{array}{l}\text { Left hemiparesis, developmental } \\
\text { delay }\end{array}$ & 6 \\
\hline Case 7 & 24 & $\mathrm{~F}$ & Maori & $\begin{array}{l}\text { Left SDH, bilateral } \mathrm{RH} \text {, } \\
\text { bilateral retinoschisis }\end{array}$ & 1 & $\mathrm{~b}$ & $\mathrm{~b}$ & & Died & 8 \\
\hline Case 8 & 36 & $\mathrm{~F}$ & Maori & Right $\mathrm{SDH}$, bilateral $\mathrm{RH}$ & $\mathrm{r}$ & $\mathrm{b}$ & $\mathrm{n}$ & & Died & 8 \\
\hline Case 9 & 17 & $\mathrm{~F}$ & Maori & Right SDH, bilateral RH & $\mathrm{r}$ & $\mathrm{b}$ & $\mathrm{n}$ & & Died & 8 \\
\hline $\begin{array}{l}\text { Case } \\
10\end{array}$ & 37 & M & Maori & Right $\mathrm{SDH}$, right $\mathrm{RH}$ & $\mathrm{r}$ & $\mathrm{r}$ & $\mathrm{n}$ & & Died & 8 \\
\hline $\begin{array}{l}\text { Case } \\
11\end{array}$ & 7 & $\mathrm{~F}$ & Maori & Left SDH, left RH & 1 & 1 & $\mathrm{n}$ & 58 & Right hemiplegia & 6 \\
\hline $\begin{array}{l}\text { Case } \\
12\end{array}$ & 5 & M & European & Bilateral SDH, bilateral $\mathrm{RH}$ & $\mathrm{b}$ & $\mathrm{b}$ & $\mathrm{n}$ & 47 & Normal & 1 \\
\hline $\begin{array}{l}\text { Case } \\
13\end{array}$ & 6 & M & Maori & Right $\mathrm{SDH}$, right $\mathrm{RH}$ & $\mathrm{r}$ & $\mathrm{r}$ & $\mathrm{n}$ & 45 & Normal & 1 \\
\hline $\begin{array}{l}\text { Case } \\
14\end{array}$ & 3 & M & Maori & $\begin{array}{l}\text { Right } \mathrm{SDH} \text {, bilateral } \mathrm{RH}, \\
\text { right retinoschisis }\end{array}$ & $\mathrm{r}$ & $\mathrm{b}$ & $\mathrm{r}$ & 63 & Normal & 1 \\
\hline $\begin{array}{l}\text { Case } \\
15\end{array}$ & 12 & $\mathrm{~F}$ & Maori & Bilateral SDH, bilateral $\mathrm{RH}$ & $\mathrm{b}$ & $\mathrm{b}$ & $\mathrm{n}$ & 36 & $\begin{array}{l}\text { Severe developmental and speech } \\
\text { delays, quadriplegia, PEG fed }\end{array}$ & 6 \\
\hline $\begin{array}{l}\text { Case } \\
16\end{array}$ & 7 & $\mathrm{~F}$ & European & $\begin{array}{l}\text { Bilateral SDH, bilateral } \mathrm{RH}, \\
\text { right retinoschisis }\end{array}$ & $\mathrm{b}$ & $\mathrm{b}$ & $\mathrm{r}$ & 55 & Normal & 1 \\
\hline $\begin{array}{l}\text { Case } \\
17\end{array}$ & 12 & M & Maori & Bilateral SDH, bilateral RH & $\mathrm{b}$ & $\mathrm{b}$ & $\mathrm{n}$ & 40 & $\begin{array}{l}\text { Mild developmental and speech } \\
\text { delay }\end{array}$ & 3 \\
\hline $\begin{array}{l}\text { Case } \\
18\end{array}$ & 1 & M & European & Bilateral SDH, bilateral RH & $\mathrm{b}$ & $\mathrm{b}$ & $\mathrm{n}$ & 30 & Global developmental delay & 5 \\
\hline $\begin{array}{l}\text { Case } \\
19\end{array}$ & 25 & $\mathrm{~F}$ & European & $\begin{array}{l}\text { Bilateral } \mathrm{SDH} \text {, bilateral } \mathrm{RH}, \\
\text { bilateral retinoschisis }\end{array}$ & $\mathrm{b}$ & $\mathrm{b}$ & $\mathrm{b}$ & & Died & 8 \\
\hline $\begin{array}{l}\text { Case } \\
20\end{array}$ & 10 & M & Maori & $\begin{array}{l}\text { Bilateral SDH, bilateral RH, } \\
\text { bilateral retinoschisis }\end{array}$ & $\mathrm{b}$ & $\mathrm{b}$ & $\mathrm{b}$ & & Died & 8 \\
\hline $\begin{array}{l}\text { Case } \\
21\end{array}$ & 15 & M & Maori & Left SDH, bilateral $\mathrm{RH}$ & 1 & $\mathrm{~b}$ & $\mathrm{n}$ & 39 & Speech developmental delay & 3 \\
\hline $\begin{array}{l}\text { Case } \\
22\end{array}$ & 7 & M & Maori & $\begin{array}{l}\text { Left SDH, bilateral } \mathrm{RH}, \\
\text { right retinoschisis }\end{array}$ & 1 & $\mathrm{~b}$ & $\mathrm{r}$ & 21 & Normal & 1 \\
\hline $\begin{array}{l}\text { Case } \\
23\end{array}$ & 2 & $\mathrm{~F}$ & MELAA & $\begin{array}{l}\text { Bilateral } \mathrm{SDH} \text {, bilateral } \mathrm{RH}, \\
\text { bilateral retinoschisis }\end{array}$ & $\mathrm{b}$ & $\mathrm{b}$ & $\mathrm{b}$ & & Died & 8 \\
\hline $\begin{array}{l}\text { Case } \\
24\end{array}$ & 22 & $\mathrm{~F}$ & Maori & $\begin{array}{l}\text { Bilateral SDH, bilateral } \mathrm{RH}, \\
\text { bilateral retinoschisis }\end{array}$ & $\mathrm{y}$ & $\mathrm{b}$ & $\mathrm{b}$ & & Died & 8 \\
\hline $\begin{array}{l}\text { Case } \\
25\end{array}$ & 12 & M & Maori & Right SDH, bilateral RH & $\mathrm{r}$ & $\mathrm{b}$ & $\mathrm{n}$ & 36 & Normal & 1 \\
\hline $\begin{array}{l}\text { Case } \\
26\end{array}$ & 5 & M & Maori & Bilateral SDH, left RH & $\mathrm{b}$ & 1 & $\mathrm{n}$ & 16 & Normal & 1 \\
\hline $\begin{array}{l}\text { Case } \\
27\end{array}$ & 3 & M & Maori & Bilateral SDH, bilateral RH & $\mathrm{b}$ & $\mathrm{b}$ & $\mathrm{n}$ & 17 & Global developmental delay & 6 \\
\hline $\begin{array}{l}\text { Case } \\
28\end{array}$ & 2.5 & M & Maori & Bilateral SDH, right $\mathrm{RH}$ & $\mathrm{b}$ & $\mathrm{r}$ & $\mathrm{n}$ & 35.5 & Mild speech delay & 2 \\
\hline $\begin{array}{l}\text { Case } \\
29\end{array}$ & 4 & M & Maori & $\begin{array}{l}\text { Bilateral } \mathrm{SDH} \text {, bilateral } \mathrm{RH}, \\
\text { bilateral retinoschisis }\end{array}$ & $\mathrm{b}$ & $\mathrm{b}$ & $\mathrm{b}$ & 22 & $\begin{array}{l}\text { Severe global developmental delay, } \\
\text { impaired feeding (PEG fed) }\end{array}$ & 6 \\
\hline $\begin{array}{l}\text { Case } \\
30\end{array}$ & 4 & M & Maori & $\begin{array}{l}\text { Right } \mathrm{SDH} \text {, bilateral } \mathrm{RH}, \\
\text { left retinoschisis }\end{array}$ & $\mathrm{r}$ & $\mathrm{b}$ & 1 & 15 & Cerebral palsy, seizures, hemiplegia & 6 \\
\hline $\begin{array}{l}\text { Case } \\
31\end{array}$ & 7 & M & European & $\begin{array}{l}\text { Bilateral SDH, bilateral } \mathrm{RH}, \\
\text { right retinoschisis }\end{array}$ & $\mathrm{b}$ & $\mathrm{b}$ & $\mathrm{r}$ & 18 & $\begin{array}{l}\text { Severe global developmental delay, } \\
\text { impaired feeding (PEG fed) }\end{array}$ & 6 \\
\hline
\end{tabular}


Table 2. (Continued)

\begin{tabular}{|c|c|c|c|c|c|c|c|c|c|c|}
\hline \multirow[t]{2}{*}{ Subject } & \multirow{2}{*}{$\begin{array}{l}A I \\
(m o)\end{array}$} & \multirow[t]{2}{*}{ Gender } & \multirow[t]{2}{*}{ Ethnicity } & \multirow[t]{2}{*}{ Clinical features } & \multicolumn{3}{|c|}{ Clinical features } & \multirow{2}{*}{$\begin{array}{l}A F \\
(m o)\end{array}$} & \multirow[t]{2}{*}{ Neurol sequelae } & \multirow{2}{*}{$\begin{array}{l}\text { GOS- } \\
\text { E Ped }\end{array}$} \\
\hline & & & & & $S D H$ & RH & Retinoschisis & & & \\
\hline $\begin{array}{l}\text { Case } \\
32\end{array}$ & 5 & $\mathrm{~F}$ & Maori & Bilateral SDH, bilateral RH & $\mathrm{b}$ & $\mathrm{b}$ & $\mathrm{n}$ & 20 & Normal & 1 \\
\hline $\begin{array}{l}\text { Case } \\
33\end{array}$ & 10 & M & $\begin{array}{l}\text { Pacific } \\
\text { people }\end{array}$ & Left SDH, left RH & 1 & 1 & $\mathrm{n}$ & 21 & Normal & 1 \\
\hline $\begin{array}{l}\text { Case } \\
34\end{array}$ & 6 & M & Maori & Left SDH, bilateral RH & 1 & $\mathrm{~b}$ & $\mathrm{n}$ & 20 & Speech developmental delay & 3 \\
\hline $\begin{array}{l}\text { Case } \\
35\end{array}$ & 4 & M & Maori & $\begin{array}{l}\text { Bilateral SDH, bilateral RH, } \\
\text { bilateral retinoschisis }\end{array}$ & $\mathrm{b}$ & $\mathrm{b}$ & $\mathrm{b}$ & 23 & Normal & 1 \\
\hline $\begin{array}{l}\text { Case } \\
36\end{array}$ & 7 & $\mathrm{~F}$ & Maori & Bilateral SDH, left RH & $\mathrm{b}$ & 1 & $\mathrm{n}$ & 19 & Normal & 1 \\
\hline $\begin{array}{l}\text { Case } \\
37\end{array}$ & 3 & $\mathrm{~F}$ & European & Left SDH, left RH & 1 & 1 & $\mathrm{n}$ & 19 & Normal & 1 \\
\hline $\begin{array}{l}\text { Case } \\
38\end{array}$ & 6 & M & Maori & $\begin{array}{l}\text { Bilateral SDH, bilateral } \mathrm{RH} \text {, } \\
\text { left retinoschisis }\end{array}$ & $\mathrm{b}$ & $\mathrm{b}$ & 1 & & Died & 8 \\
\hline
\end{tabular}

Abbreviations: AI (mo), age at injury in months; AF (mo), age at follow-up in months; F\&F, fixes and follows; GOS-E Ped, Glasgow Outcome ScoreExtended Pediatric version; MELAA, Middle Eastern, Latin American and African; NPL, no perception of light; PL, perception of light; RH, retinal haemorrhage; SDH, subdural haemorrhage.

Table 3 Visual outcomes of children with/without retinoschisis

\begin{tabular}{lccc}
\hline Retinoschisis & \multicolumn{3}{c}{ Visual acuity } \\
\cline { 2 - 4 } & Better than 6/12 & $6 / 12-6 / 60$ & Worse than 6/60 \\
\hline Present & 2 & 2 & 3 \\
Absent & 9 & 1 & 1 \\
\hline
\end{tabular}

retinoschisis was associated with an approximate sevenfold increase in poor long-term neurological outcome and associated with higher rate of mortality in the present study. Arguably, macular retinoschisis is one of the specific ocular signs of NAI and potentially be a crucial diagnostic feature. ${ }^{23}$ The ocular autopsy and histopathology of 118 cases noted the presence of macular retinoschisis in about $23 \%$ of deceased children. ${ }^{24}$

Furthermore, a smaller published case series of 10 children has reported significant association of macular retinoschisis with a fatal outcome ${ }^{15}$ Figure 1.

$\mathrm{SDH}$ often co-exists with retinal haemorrhages and the two are key features of NAI. ${ }^{25}$ Although, the severity of injury can be associated with findings of bilateral SDH and retinal haemorrhage, the current study did not show statistical significance. It is generally accepted that the more severe the intracranial bleed and the more extensive the retinal haemorrhages, the more severe the mechanism of injury. ${ }^{26}$ However, current study only accounted for the presence of $\mathrm{SDH}$, retinal haemorrhages, and retinoschisis, rather than the extent of injury that could have resulted in statistically insignificant results. The presence of bilateral SDH and retinal haemorrhage
Table 4 Distribution of neurological outcomes affecting children aaccording to age when injury afflicted

\begin{tabular}{|c|c|c|c|c|c|c|c|c|}
\hline \multirow[t]{2}{*}{ Age (months) } & \multicolumn{8}{|c|}{ GOS-E Ped } \\
\hline & 1 & 2 & 3 & 4 & 5 & 6 & 7 & 8 \\
\hline 1 & & & & & 1 & & & \\
\hline 2 & & & & & & & & 1 \\
\hline 3 & 2 & 1 & & 1 & & 1 & & 2 \\
\hline 4 & 1 & & & & & 1 & & \\
\hline 5 & 3 & & & & & & & \\
\hline 6 & 1 & & 1 & & & & & 1 \\
\hline 7 & 3 & & & & & 3 & & \\
\hline 8 & 1 & & & & & & & \\
\hline 10 & 1 & & & & & & & 1 \\
\hline 12 & 1 & & & & & 1 & & \\
\hline 14 & & & & & & & & 1 \\
\hline 15 & & & 1 & & & & & \\
\hline 17 & & & & & & & & 1 \\
\hline 22 & & & & & & & & 1 \\
\hline 24 & & & & & & & & 1 \\
\hline 25 & & & & & & & & 1 \\
\hline 36 & & & & & & & & 1 \\
\hline 37 & & & & & & & & 1 \\
\hline
\end{tabular}

corresponds to a three-fold increase of poor long-term neurological outcome as compared with unilateral findings. NAI children with SDH carry a poor prognosis, with three-quarters die or live with profound disability. ${ }^{3}$

Reportedly, the severity of retinal haemorrhage is significantly associated with acute neurological injury. ${ }^{27}$ A systematic review of about thousand cases that included meta-analysis of five studies reported a strong correlation of retinal haemorrhages and NAI (or abusive head injury) with an odds ratio of 14.7 and $91 \%$ 


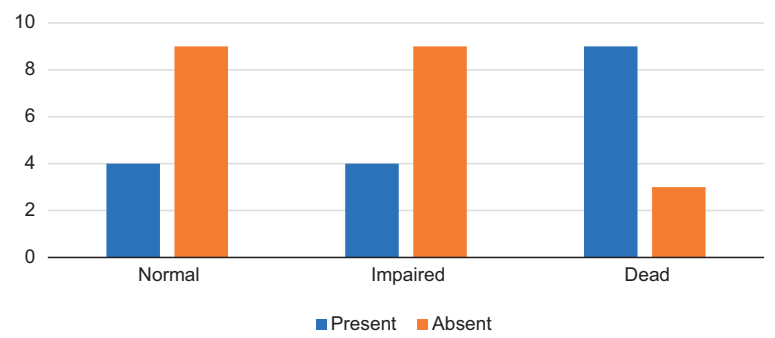

Figure 1 Neurological outcomes of children with/without retinoschisis.

probability. ${ }^{26}$ Similar to the current study, bilateral involvement also had significant association. ${ }^{26}$ Typically, macular retinoschisis, retinal haemorrhages, and acute encephalopathy are noted in NAI. ${ }^{13,14}$

An incidental finding of this study was a two-fold increase in prevalence of NAI in Māori children compared with the other ethnic groups in New Zealand. This unfortunate outcome is supported by other reports of higher incidence of childhood visual impairment and non-accidental injuries in Māori children. ${ }^{28}$

This study has limitations due to the nature of being a retrospective study. Although the limited sample size is a limitation of this study where results have failed to reach statistical significance, a trend is noted with worse longterm neurological function when SDHs and retinal haemorrhages were bilateral and if retinoschisis was present. Collectively, these signs offer prognostic factors of long-term neurological outcome.

\section{Conclusion}

In conclusion, this study reports on the presence of retinoschisis in the event of NAI to have an approximate seven-fold increase in the risk of poor long-term neurological outcome, including death. The findings of a younger age of injury corresponding with better neurological outcome in this cohort differs from other published reports. Good neuroplasticity in children allows better neurological outcome at a later stage is a possible explanation for this unexpected result.

\section{Summary}

\section{What was known before}

- Non-accidental head injury in children causes long-term deleterious effects in growth and development of the child (if the child survives the initial insult).

\section{What this study adds}

- Prognostication of long-term neurological outcome following non-accidental head injury, taking into account the presence of: (1) retinoschisis and (2) the age of the child at the time of injury.

\section{Conflict of interest}

The authors declare no conflict of interest.

\section{Acknowledgements}

We thank The University of Auckland and Blind and Low Vision Education Network New Zealand, Homai Campus, Auckland, New Zealand.

\section{References}

1 Barlow K, Thompson E, Johnson D, Minns RA. The neurological outcome of non-accidental head injury. Dev Neurorehabil 2004; 7(3): 195-203.

2 David TJ. Shaken baby (shaken impact) syndrome: nonaccidental head injury in infancy. J R Soc Med 1999; 92(11): 556.

3 Jayawant S, Rawlinson A, Gibbon F, Price J, Schulte J, Sharples $P$ et al. Subdural haemorrhages in infants: population based study. BMJ 1998; 317(7172): 1558-1561.

4 Minns RA, Jones PA, Mok JYQ. Incidence and demography of non-accidental head injury in southeast Scotland from a national database. Am J Prev Med 2008; 34(4): S126-S133.

5 Barlow KM, Minns RA. Annual incidence of shaken impact syndrome in young children. Lancet 2000; 356(9241): 1271-1272.

6 Hobbs C, Childs AM, Wynne J, Livingston J, Seal A. Subdural haematoma and effusion in infancy: an epidemiological study. Arch Dis Child 2005; 90(9): 952-955.

7 Kelly P, Farrant B. Shaken baby syndrome in New Zealand, 2000-2002. J Paediatr Child Health 2008; 44(3): 99-107.

8 Feigin VL, Theadom A, Barker-Collo S, Starkey NJ, McPherson K, Kahan M et al. Incidence of traumatic brain injury in New Zealand: a population-based study. Lancet Neurol 2013; 12(1): 53-64.

9 Maguire SA, Watts PO, Shaw AD, Holden S, Taylor RH, Watkins WJ et al. Retinal haemorrhages and related findings in abusive and non-abusive head trauma: a systematic review. Eye (Lond) 2013; 27(1): 28-36.

10 Vincent AL, Kelly P. Retinal haemorrhages in inflicted traumatic brain injury: the ophthalmologist in court. Clin Exp Ophthalmol 2010; 38(5): 521-532.

11 Bechtel KSK, Leventhal JM, Ogle E, Teague B, Lavietes S, Banyas B et al. Characteristics that distinguish accidental from abusive injury in hospitalized young children with head trauma. Pediatrics 2004; 114(1): 165-168.

12 Lantz PE, Sinal SH, Stanton CA, Weaver RG Jr. Perimacular retinal folds from childhood head trauma. BMJ 2004; 328(7442): 754-756.

13 Morad Y, Wygnansky-Jaffe T, Levin AV. Retinal haemorrhage in abusive head trauma. Clin Exp Ophthalmol 2010; 38(5): 514-520.

14 Watts P, Obi E. Retinal folds and retinoschisis in accidental and non-accidental head injury. Eye 2008; 22(12): 1514-1516.

15 Mills M. Funduscopic lesions associated with mortality in Shaken baby syndrome. J AAPOS 1998; 2: 67-71.

16 Wilkinson WS, Han Dennis P, Rappley Marsha D, Owings Clyde L. Retinal haemorrhage predicts neurologic injury in shaken baby syndrome. Arch Ophthalmol 1989; 107: 1472-1474. 
17 Beers SR, Wisniewski SR, Garcia-Filion P, Tian Y, Hahner T, Berger RP et al. Validity of a pediatric version of the Glasgow Outcome Scale-Extended. J Neurotrauma 2012; 29(6): 1126-1139.

18 Anderson V, Catroppa C, Morse S, Haritou F, Rosenfeld J. Recovery of intellectual ability following traumatic brain injury in childhood: impact of injury severity and age at injury. Pediatr Neurosurg 2000; 32(6): 282-290.

19 Filley CM, Cranberg LD, Alexander MP, Hart EJ. Neurobehavioral outcome after closed head injury in childhood and adolescence. Arch Neurol 1987; 44(2): 194-198.

20 Duncanson M, Smith DA, Davies E. Death and Serious Injury from Assault of Children Under 5 years in Aotearoa New Zealand: A Review of International Literature and Recent Findings. [Internet]. Office of the Chilren's Commisioner: Wellington, New Zealand 2009.

21 Barlow KM, Thomson E, Johnson D, Minns RA. Late neurologic and cognitive sequelae of inflicted traumatic brain injury in infancy. Pediatrics 2005; 116(2): 174-185.

22 Prasad MR, Ewing-Cobbs L, Swank PR, Kramer L. Predictors of outcome following traumatic brain injury in young children. Pediatr Neurosurg 2002; 36(2): 64-74.
23 Massicotte SJ, Folberg R, Torczynski E, Gilliland MGF, Luckenbach MW. Vitreoretinal traction and perimacular retinal folds in the eyes of deliberately traumatized children. Ophthalmology 1991; 98(7): 1124-1127.

24 Emerson MV, Jakobs E, Green WR. Ocular autopsy and histopathologic features of child abuse. Ophthalmology 2007; 114(7): 1384-1394.

25 Mian M, Shah J, Dalpiaz A, Schwamb R, Miao Y, Warren K et al. Shaken baby syndrome: a review. Fetal Pediatr Pathol 2015; 34(3): 169-175.

26 Maguire SA, Watts PO, Shaw AD, Holden S, Taylor RH, Watkins WJ et al. Retinal haemorrhages and related findings in abusive and non-abusive head trauma: a systematic review. Eye 2013; 27(1): 28-36.

27 Wilkinson WS, Han DP, Rappley MD, Owings CL. Retinal hemorrhage predicts neurologic injury in the shaken baby syndrome. Arch Ophthalmol 1989; 107(10): 1472-1474.

28 Chong CF DS. Cross-sectional study on prevalence, causes and avoidable causes of visual impairment in Māori children. New Zeal Med J 2013; 126: 1379. 